


\section{„Sonderjydske Aarbogerer"}

udgives af

H. P. Hanssen-Nopremolle, Gurstar Johannsen og P. Skau.

,Sønderjydske Aarbøger“" vil bringe Bidrag til Sønderjyllands Historie og Topographi, Skildringer af Folkelivet i Sønderjylland, politiske Afhandlinger om Nutidsforhold i Sønderjylland $\mathrm{m} . \mathrm{m}$.

Subskription paa "Sønderjydske Aarbøger" modtages i alle Boglader i Sønderjylland, Danmark, Norge og Sverrig. Prisen er 4 Kroner Aargangen; for Medlemmer af danske Foreninger i Nordslesvig 3 Mark.

\section{Indhold:}

J. Fausbøl: Polakkerne i Nordslesvig . . . . . . . Side 177. Axel Olrik: Iver Ottesøn og Hr. Buske .. . . . . . . . 190. N. J. Ravn: Jens Lauritzen Skau . . . . . . . . . . 197. C. R.: N. J. Ravn. . . . . . . . . . . . . . . . 205.

Nis Hanssen: Allerunderdanigst Fremstilling af nogle Iagttagelser paa en Rejse gjennem det østlige Slesvig . . 207.

M. H. Niolsen: Godske Rantzov og Selvejerne i Løg Herred 225.

L. Petersen: Ungdomsminder fra vort Modersmaals sydligste Græenseegne. . . . . . . . . . . . . . . 251 Indbydelse. . . . . . . . . . . . . . . . . . . 275. Thygesen: To Dekumenter vedkommende Tyreholdet i Stendrup By i det 16de Aarhundrede . . . . . . . . 278. En preussisk Dom fra Anno 1895 . . . . . . . . . . 282.

NB. En Række Forhold, som Redaktionen ikke har været Herre over, har forsinket Udgivelsen af dette Hæfte.

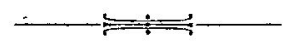

